\title{
Ricarda Wagner
}

\section{Tablets and the Poetics of the Premodern Post-It}

This chapter explores one of the most familiar text-bearing objects of the Middle Ages. Tablets, sized to be hand-held, initiated writers into the world of literacy. Forbearing and compliant, their waxen surfaces offered themselves to both a student's first attempts at lettering and the confident compositions of a more practised hand. Portable and adaptable to a variety of uses, tablets served as personal companions carried on the body, ready at hand to receive a fleeting thought, an inventory, a calculation, a legal agreement or the first draft of a poem. ${ }^{1}$ While hand-held formats and girdle-books suspended from belts were the most common, tablets of varying size could be attached to the writer's person in any number of ways. Charlemagne, for example, was said to have worn a tablet around his neck while learning the alphabet. Tablets, then, lend themselves to everyday writing, but luxury specimens also survive, made of ivory rather than wood and exquisitely decorated to be given as love gifts. ${ }^{2}$

Locomobile and handy, tablets form close associations with their writers and bearers. In this chapter, I will examine such tablet-assemblages in medieval English, German and French literature that associate wax, wood, ivory, brass, clay and stone with lovers, poets and parents. As we shall see, the material vitality of inscribed tablets intersects with desire and doubt, sin and penitence, ancestry and origins. As personal writing companions, tablets provide an interface to express private matters and communicate intimacy. Fashioned for the single purpose of bearing text, they recycle easily and, in case their material is soft enough to yield to even gentle pressure, particularly lend themselves to ephemeral writing that is traced as quickly as it is erased.

But the private, hand-held version is not the only form of the medieval tablet. Literary sources also apply the term to plaques, sheet-like pieces of writing affixed to a surface where they may be read by anyone who passes by. In contrast to books, mounted tablets reveal texts that cannot be closed, and exhibit writing that faces us at all times. I shall argue that such inscribed plaques function as "premodern post-its" which supplement the exterior of a different object with material text. Being merely add-ons, these post-its must permanently confront the threat of being removed again,

\footnotetext{
1 Cf. Bourgne 2011, 127-132 for a number of interesting examples that trace the medieval opposition between the wax tablet, mainly used for preparatory writing, and the ink and parchment employed for clean copies.

2 Cruse 2007, for instance, analyses an impressive fourteenth-century ivory tablet kept at The Cloisters and proposes to understand it as a medieval Valentine's card. Brown 1994 lists more luxury examples of tablets (10) and discusses general uses of tablets in the Middle Ages (4-9), including Charlemagne's (8). For the vocabulary that medieval sources employ with regard to tablets and their inscription, see Rouse/Rouse 2013, 14.
}

Ә Open Access. (C) 2019 Ricarda Wagner, published by De Gruyter. (c) BY-NC-ND This work is licensed under the Creative Commons Attribution-NonCommercial-NoDerivatives 4.0 License. 
their message becoming as ephemeral as the faint letters on a wax tablet. Both the detachable plaque and the erasable hand-held tablet, then, offer their writers and readers a certain degree of control over how long their texts will be visible. As this chapter aims to show, tablets encompass significant opposites in medieval textual and material culture; they are fashioned as personal accessories and public post-its, bearing both temporary scribblings and enduring text.

Dating back to the very beginnings of human verbal expression, the tablet was first devised as a surface on which to materialise memory and to account for things. Clay tablets from ancient Mesopotamia, easy to produce, reusable and inscribed with cuneiform letters, are among the earliest sources for script. About $95 \%$ of these tablets, some of them no larger than a credit card, were used to record the ownership of assets. $^{3}$ While the concept of personal property galvanised the development of writing, cultural treasures in the form of stories were also codified in clay. For the select class of Akkadian and Babylonian scribes, however, tablets were only ever an aid to memory. As texts were not meant to be read by anyone who did not already know them, their transmission in cuneiform merely assisted the scribe's progress in learning them by heart. In schools, which the Akkadians called "tablet houses", teachers would instruct their students how to inscribe texts not only in clay, but also in their minds. This double practice of writing and memorising gave rise to the trope of the "tablet of the heart". Commonly used in the didactic exhortations of ancient Mesopotamian and Biblical texts, it encouraged students to conceive of their memory as a workable surface ready to be incised. ${ }^{4}$

The secular literature of the Middle Ages employs the tablet as a metaphor in a related sense, adapting it to discourses of courtly love and desire. Here, the waxen surface and the wooden frame no longer represent the writer's memory, but serve as an interface to reveal and communicate his or her feelings. This type of "tablet of the heart" is not so much about learning to recall as it is about learning to express, and about daring to materialise interiority. ${ }^{5}$ As text-bearing artefacts rather than metaphors, the tablets we find in imaginative literature are personal writing accessories that negotiate emotional rather than cognitive knowledge. Interestingly, as the CRC's database shows, these material tablets of the heart feature predominantly in romances that rework texts of classical Roman literature.

The medieval romance of Eneas, written in French around 1160 and adapted into German by Heinrich von Veldeke shortly thereafter, retells Virgil's Aeneid, but significantly expands the character of Lavinia, the Italian princess Aeneas/Eneas is

3 Cf. Robson 2007, 67-71 on Mesopotamian uses, forms and production of tablets.

4 Carr 2005, 20-40 discusses the Mesopotamian connection between tablets and memory. He notes that the trope of the tablet of the mind was also prevalent in Ancient Greece (98) and central to the Torah (127). Cf. also Jager 1996, $4 \mathrm{f}$.

5 For more on inscribed hearts, see Stephanie Béreiziat-Lang's and Michael R. Ott's chapter on body and skin in this volume, especially pp. 201-203. 
destined to marry. While her part in Virgil is silent and limited to references by other characters, both the French and the German versions of the romance zoom in closely on Lavinia's struggle to come to terms with her burgeoning feelings of love for the hero newly arrived from Troy. When her mother notices Lavinia's malaise and puts her on the spot, the princess shies away from naming the man she loves. In the German Eneasroman, Lavinia is prompted by her mother to put the name in writing:

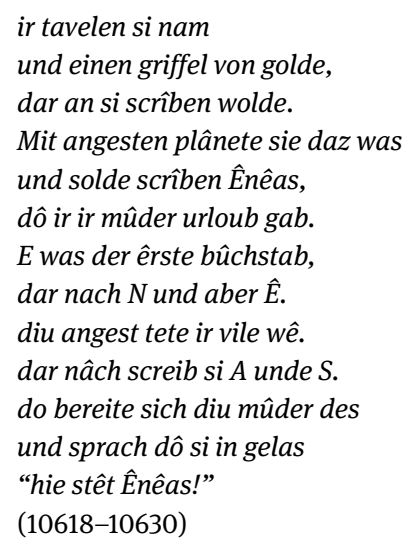

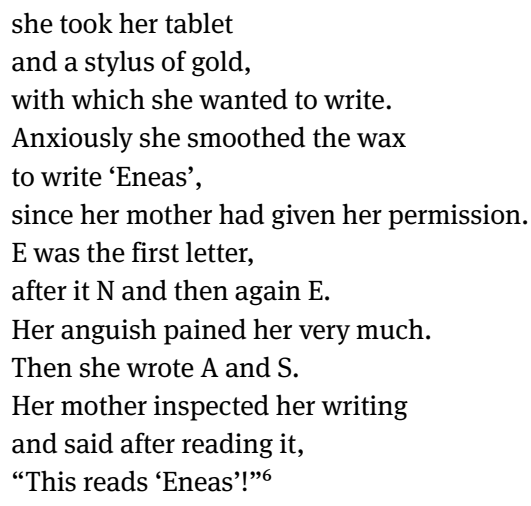

At least to the modern reader, the scene is almost comical. Before Lavinia slowly draws every letter of her beloved's name so that her mother can display her impressive reading skills, the Eneasroman devotes considerable space to oral discourses on love. Mother and daughter sit together to talk about the best possible suitor, the physical signs of love and the painful pleasure of its impact for a total of 200 verses (9750-9968). The tablet scene, too, is preceded by a lengthy conversation between the two on daz sûze ungemach ("the sweet misery", 10532). In addition to these dialogues in which the queen imparts her wisdom in all matters of the heart, the text presents a soliloquy of an astonishing 400 verses that Lavinia sprach [...] ir selber jâmmerlîche $z \hat{u}$ ("delivered to herself woefully", 10062) in an attempt to work out her feelings and thoughts after falling in love with Eneas at first sight. ${ }^{7}$ Since she had previously given voice to complex philosophical issues debated with her mother and herself, why does Lavinia not simply speak Eneas's name out loud when asked?

Rather than pronouncing her answer, the princess reaches for her writing materials, creating what Jane Bennett, with a nod to Deleuze/Guattari, describes as an "assemblage", a spontaneous grouping of material bodies, persons and things. ${ }^{8}$ In

6 All translations from the medieval vernaculars into English are my own.

7 Cf. Cormier 2006, 68-70, who has identified nine steps on Lavinia's path to emotional knowledge that he relates to sections of her monologues and other self-expressions.

8 Bennett 2010, 23. The concept of assemblages and its relevance for text-bearing artefacts is also discussed in the introduction to this volume, p. $4 \mathrm{f}$. 
an assemblage, agency is not the privilege of a single entity, but is distributed among the members of the association. While Lavinia guides the stylus, its golden tip incises the wax that forms the letters which Lavinia's mother, holding the tablet in her hands in turn, combines to proclaim her daughter's love for a foreigner. The writing surface offers itself as "a tablet of the heart" that materialises the object of Lavinia's desire. By revealing her secret, the inscription spells out the goal of the lesson the princess had been learning orally.

At the same time, the tablet demands a labour of Lavinia in return for concluding her quest for emotional knowledge. While the air that reverberates with spoken sounds offers no resistance, the materiality of the wax forces her to scratch away with her stylus, to displace matter. Lavinia must first smooth the wax (plânete daz was, 10621) and then incise the letters, which she does slowly and in agony (angesten, 10621; 10626). She knows that her mother will disapprove of her desire for Eneas and wishes her to marry the Italian prince Turnus instead. But as the princess toils over her inscription, the material conditions recall that the writer herself has undergone an equally exacting process. While a fierce war for the future rule of Latium was raging around her between the conquering Eneas and the defending Turnus, Lavinia, through her soliloquy and dialogues with her mother, managed to negotiate the pressures of politics and her personal wishes. What she sets down in writing with considerable effort is her female power of choice, catalysed by the interfering goddess of love, but carefully evaluated nonetheless. ${ }^{9}$

The significance of Lavinia's inscription on the tablet becomes especially clear when compared to another scene of the text in which a woman reveals her love for Eneas. When Dido, smitten with the Trojan hero after his arrival at Carthage, confides in her sister Anna that she is suffering from love for a man, Anna presses her to disclose who it is. Like Lavinia, Dido hesitates at first but finally relents. But rather than writing down the name of her beloved, Dido spells it out:

"her heizet", sprach si "der $\hat{E}$ und dar nâch NÊ." uber lank, alsô sie diu minne dwank, ê si vollesprâche $A S$

(1530-1533)

\author{
"he is called", she said, "E \\ and then NE" hesitantly, \\ as Love forced her, \\ before she concluded AS.
}

9 Drawing on Vilém Flusser's thoughts on inscriptionality, Wuth 1997, 75f. reads Lavinia's incision as an example of an ordering spirit transforming chaos into cosmos. He correlates this scene in the romance of Eneas with larger developments consolidating the practice of writing around the year 1200 . Focussing on the letter that Lavinia later sends to Eneas to communicate her feelings in the French Roman, Nolan 1992, 79, 92-95 and Adams 2005, 124-129 also maintain that Lavinia gains self-knowledge and mastery of the discourse of love through writing. I argue that Lavinia's initiation into the textual discourse of love starts earlier, with her inscription in wax. 
Dido's letter-by-letter revelation is echoed by Lavinia's equally slow, tortured inscription later, but also recalls the French version of the scene between the Italian princess and her mother. In the Roman d'Eneas, Lavinia does not write on her wax tablet, but spells out Eneas's name exactly as Dido does in Heinrich von Veldeke's German text. Heinrich, then, makes two changes to his French template: By having his Dido spell out orally and slowly, who in the French version simply pronounces Eneas's name (cf. 1322), and by making Lavinia incise her tablet, Heinrich sets his Italian princess apart. ${ }^{10}$ As the Eneasroman transfers the utterance to Dido and parallelises the two scenes, Lavinia's inscription stresses the difference between her and the abandoned queen of Carthage: Lavinia's love for Eneas is not an idle fancy, but fate; it is written. Her union with the Trojan hero is not the hushed whisper of myth, but the inscribed certainty of history.

Lavinia's inscription certainly marks the beginning of a desire that, once communicated to her mother by tablet and then to her beloved by letter, is fulfilled. In the Ovide moralisé, in contrast, revealing one's tablet of the heart entails pain and calamity. The fourteenth-century French adaptation of Ovid's Metamorphoses reworks the story of Byblis, whose disastrous love for her brother Cadmus makes her story a cautionary tale for all those ladies who need to "learn not to love too madly" (prendere / Qu'eles n'aiment trop folement, 2080f.). Like the Eneasroman, the Ovide moralisé probes the emotions and thoughts of the heroine much more thoroughly than its classical source. While Ovid's Byblis only raises objections to her incestuous passion to dismiss them curtly, her French counterpart first wrestles with her feelings in a lengthy soliloquy spoken by "her heart" (son cuer, 2114) before repeating her agony while incising a confession to her brother on her wax tablet. ${ }^{11}$

This act of writing aims to convince both Cadmus and Byblis herself that their love would be permissible, but ultimately activates an assemblage that cannot hold. Byblis's urgent inscription goes hand in hand with self-censorship. Drawing on the trope of the tablet of the heart, she makes clear that she considers such an inscription a special kind of communication:

"Et se je lais pour honte à dire, Je li demanderai par cire, Savoir li ferai par escrit Ce que j'ai en mon cuer escrit” (9.2227-2230)

\author{
"And if I am too ashamed to say it, \\ I will ask him by wax, \\ I will let him know by writing \\ What is written on my heart."
}

10 Cf. Quast/Schausten 2008 for a comparison between the French and the German version with regard to discourses of love. In Heinrich's version, they argue, love takes on a physical quality and can be transmitted by touch, which agrees well with Lavinia's need to materialise the name of her beloved. 11 The German tale of Gregorius by Hartmann von Aue (twelfth century), also features a tablet bearing a story of incestuous sin written by a woman. Cf. Laura Velte's and Michael R. Ott's chapter on inscriptions in medieval German literature in this volume. 
The rhyme dire : cire is ironic since the following verses reveal that Byblis's incising her tablet is anything but a straightforward process of enunciation. Saying something "by wax" (par cire) in her case implies a continued elimination of the writer's words. Byblis composes a few lines on her tablet, “deletes" them (dapna, 2246), starts afresh, "erases" again (efface, 2247) and again (2249), and "smooths" the wax (aplaine, 2249) only to "re-delete and blot out" (redapne si l'efface, 2257) twice more (2259), all "in great pain" (en grant paine, 2250). Her self-repression culminates in her decision to omit her own name and the identifier "sister" (Seror, 2254) from the letter addressed to her brother.

When consigning her letter to a messenger who is to carry it to Cadmus, Byblis drops the tablet on the floor, an event whose ominous connotations both she and the narrator note. This momentary disruption prefigures the action of Cadmus, who, having read the missive, "threw the inscription away in anger" (L'escript gita par maltalent, 2368). The tablet does not reappear after this, and in some versions of the story even breaks to pieces. ${ }^{12}$ It seems that no entity that forms part of the love-letter-assemblage actually wants Byblis's petition to succeed. While the waxen surface prompts countless rewritings, the resulting palimpsest is still not a perfect, pleasing composition, but one tainted by excess, without space for even "one more verse" (plus un vers, 2341). What Byblis experiences is a kind of "un-desire" that insists on being materialised on the waxen tablet of the heart, but is rejected by both the horrified recipient and the doubting (douteuse, 2248) sender. Like dark energy, Byblis's un-desire is effective-inscribing itself on her tablet of the heart-but ultimately unattainable.

The text-bearing tablet not only functions as a letter to be discarded, but also allows the narrator to offer a different reading of Byblis as her story continues. After being rejected by Cadmus, Byblis decides to roam the world and offer her love freely to anyone who desires her before being turned into a fountain. While first condemning both Byblis's relations with her brother and with an indeterminate number of men as "whoredom" (putage, 2102; puterie, 2468), the moralising narrator offers a stunning reversal of his judgement of the heroine after her metamorphosis. He reinterprets the wandering Byblis as the epitome of virtue first drawn to, but then fleeing from the degenerate, sinful world that Cadmus represents. Whereas such an allegorisation is a common Christian strategy to deal with classical tales of incest, ${ }^{13}$ the poet of the Ovide moralisé dares an even bolder conceit. Recalling Byblis's text-bearing artefact, he invokes another assemblage that centres around a tablet: Moses, the Israelites and God's inscribed commandments. Lithic rather than waxen, the tablets of the law differ from Byblis's letter, but are close enough in type to allow for a blending. Speaking of the heroine, the narrator reminds us that she had engaged a messenger

12 In the German prose adaptation of the Metamorphoses written by Georg Wickram in the sixteenth century, for example, Byblis's brother is so enraged after reading her letter that he warff die taffel, das sie brach ("threw the tablets so that they broke", 12.1031).

13 Cf. Archibald 2001, 68ff. 
Qui porta la table et l'escrit Ou ses secrez furenz escrit. Volt escrire o son propre doi Les comandemens de la loi Et trasmettre au peuple israël Par Moÿs, son sergant faël, Qui li presenta l'escripture (2615-2621) who carried the tablet and the inscription in which her secrets were spelled out. She/he wanted to write with her/his own finger The commandments of the law And have them delivered to the Israelites By Moses, his faithful servant, To whom he presented the inscription.

The grammatical subject of the verb volt escrire is ambivalent, referring to both Byblis from the previous sentence and the God of the Old Testament story. Merging the heroine and God via their tablet-inscriptions enables the narrator to explain his surprising re-reading of Byblis's promiscuity as Christian virtue. Both God's commandments and the letter were works of loving zeal eventually rejected by their addressees. Spurned, both writers then go out into the world to "offer their love to all” (Pour s'amour à tous presenter, 2657).

As scholars have noted, the commentary that concludes the tales in the Ovide moralisé often contradicts the moral gist of the stories, here casting an incestuous, promiscuous woman as a God-like figure in a tale that was supposed to be a warning against foolish infatuation. ${ }^{14}$ What we can learn from this striking association between Byblis and God, however, is that their tertium comparationis, the tablets, are a text-bearing artefact whose handy format caters to the extreme ends of the communicative spectrum. Tablets of the heart, as we have seen with Lavinia and Byblis, bear the private and emotional outpourings of the writer and verbalise what cannot be said. Handed from person to person, the waxen surface reveals secrets to the addressee in an assemblage with restricted members.

Stone tablets, in contrast, are bearers not of personal, but of communal memory. The codification of laws and socio-religious responsibilities on tablets is also Akkadian in origin. It left its most lasting imprint on Western culture in the form of the "tablets of the law" in the Old Testament. Inscribed by God's finger on Mount Sinai and shattered by an angry Moses at the sight of the golden calf, the stone tablets are finally refashioned to bear the Ten Commandments and document the covenant between God and the Israelites. ${ }^{15}$ As their format is associated with legal transactions and proclamations, tablets are also tasked with preserving the agreements and self-definitions that constitute a community. Depending on the materiality of their surface, then, tablets can communicate the doubtful propositions of an anguished

14 Cf. Archibald 2001, 86. Mills 2015, 146-148 explores more Christian reinterpretations of incestuous and otherwise deviant sexualities in the Ovide moralisé, such as Myrrha's desire for her father and Orpheus's passion for men.

15 Gertz 2016 examines textual history and significance of the tablets of the law in both Exodus and Deuteronomy. He also notes the similarities with Akkadian legal practices (190). 
lover par cire or the assured directions of a deity chiselled in stone. They may prescribe moral laws and carry furtive messages that seek to subvert them.

The Middle English Canticum de Creatione from the end of the fourteenth century and the prose Life of Adam and Eve from the fifteenth century recall both these configurations of tablets, the personal and the communal, in a single text-bearing artefact. The two texts form part of the apocryphal legends of Adam and Eve, a popular cluster of stories retelling the story of Genesis in more detail. ${ }^{16}$ After their expulsion from paradise, the first couple performs a lengthy penitence before they are blessed with children, among them Cain, Abel and Seth. After many centuries, Adam dies, and Eve, too, must face her end. To add to this frightening prospect, she is also made aware that God intends to destroy all life on earth. Both the Canticum and the Life recount how Eve then instructs Seth to make sure his parents' memory survives the imminent end of the world:

"Take \& make tables tweye

of al oure lyf anon,

Tweye of erthe \& tweye of ston;

Writ theron oure lyf anon

That we have had here

For longe er domesday falle

This worlde shel ben fordon alle,

By water or by fere,

Gif it be by water fordon,

Thanne shollen the tables of ston

Lasten, withouten lye;

Gif it thorghe fer be broght to nought,

Thanne the tables of erthe wroght

Lasten sikerly."

(Cant., 899-912)
"Take and make two tablets

About all our life up to now,

Two of clay and two of stone;

Write on them our life up to now

That we have had here,

Because long before doomsday falls,

This world will all be destroyed

By water or by fire.

If it be destroyed by water, Then the tablets of stone shall last, without lie;

If it be brought to nought by fire, Then the tablets made of clay

Will surely last."

Carefully planning for a possible apocalypse by water and one by fire, Eve selects stone and clay, two materials that are inscribable and can withstand at least one of these calamities. ${ }^{17}$ Seth is to make four tablets in total, two of each material, the double form perhaps anticipating the diptych Moses receives. But the text he is to incise is not a set of laws, but a personal narrative of al oure lyf anon $(900,902)$. While this plural in the Canticum may include Adam, Eve and all their descendants up to this point, Seth receives more specific instructions in the Life. Here, Eve tells him to focus exclusively on the lijf of youre fadir and of me, and tho thingis that yee han herd and seen of

16 Murdoch 2009, 1-41 and 263-266 offers an overview of the Latin apocryphal sources and corresponding vernacular versions in medieval European literature.

17 Dean 2010 explores the curiously domestic materiality in the Adam and Eve legends. 
us (Life, 97). As Sarah E. Novacich has shown, a number of late medieval narratives of Eden are concerned with archiving the details of a paradise lost. ${ }^{18}$ The tablets that Eve commissions become a record that historicises this time of beginning. Facing death, the mother of mankind wishes for her biography to endure, to chronicle her and Adam's achievements for a post-cataclysmic world that may or may not have readers.

Indeed, both the Canticum and the Life grapple with questions of literacy and readability. While Seth does as he was bid, the texts make clear that he did not manage to inscribe the tablets on his own. Rather, an angel held his hond right (Cant., 949) or, more precisely, clasped the stylus (an irun, Life, 99) as the son of Eve was writing. Being only the medium, Seth consequently has no control over what he incises, with the result that the inscribed tablets eventually contain not only the biographies of Adam and Eve, but also manye wonderful profecyes (Life, 99). As the story of the beginning of humankind needed divine assistance to be written, it likewise requires an angelic intervention to be decoded. Although the tablets were founden and seen of manye oon after the Noachian flood, they were not red (Life, 99). When a puzzled King Solomon finally discovers them, he prays to God for understanding and is enlightened by the very same angel who had helped Seth to incise them. Having learned how the inscription came about, Solomon, now turned philologist, called these lettris on these tablis Achiliacos, that is to seye, with-outen techyng of lyppis (Life, 99). ${ }^{19}$ What Seth has employed and Solomon decoded is a script "without lips", an alphabet that was never sounded, a text that defied death and destruction as pure writing. Making the antediluvian past readable offers insights into the life story of the first couple, but also reveals that that was profecyed of Adam seven sythis (Life, 99). With the help of the tablets, Solomon has uncovered not only biographical history, but also what it means.

Seth's assisted inscription links humanity's beginning to the wise King of Israel textually as well as locally. The place where Solomon found the tablets, the angel informs him, was exactly where Seth had deposited them, a location he had chosen because Adam used to worship there. Miraculously, the text-bearing artefacts, while portable, were not dislodged by the flood. They mark a holy spot, where Solomon, encouraged by the angel, proceeds to build the temple of Jerusalem. Both the tablets and the place of worship that Adam and Solomon now share identify the two men as founding fathers at the beginnings of a cultural timeline interrupted by a period of sinfulness punished with the Deluge. While the endurance of the tablets suggests continuity, the Canticum and the Life also emphasise development. By linking Adam and Solomon, they narrate the evolution from a personal to a communal religion, from a private place of worship to the great temple of a nation.

18 Cf. Novacich 2017, 25-44.

19 Murdoch 2009, 216f. discusses the term "Achiliacos" in detail, reading it as a garbled version of the Greek a-cheilos, “without lips”. 
As we have seen in the romances of Eneas and the Ovide moralisé, tablets are inscribed artefacts closely linked to the person that incises them, and come to materialise the writer's mind and heart. In the legends of Adam and Eve, in contrast, Seth, the person who inscribes the tablets, remains fairly unimportant, a mere channel for divine wisdom. Instead, the locostatic stone and clay slabs that bear the biography of the first couple come to reveal the local and material origins of Christianity. In the rest of this chapter, I will turn my attention to inscribed artefacts likewise fixed in a particular place and explore tablets used not for the intimate writing of the self, but fashioned as plaques attached to a surface visible to all passers-by.

I propose to think of such affixed tablets as "premodern post-its", material pieces of text joined to another object. Such an assemblage may serve to make the writing more visible, as in the case of a golden plaque screwed to a wooden coffin displaying the name of the deceased. Post-its also provide a way to attach writing to a surface whose own materiality cannot or must not bear it. Rather than scribbling in the margins of a book taken from the library, I stick a paper post-it in the same place to record my thoughts. This example also illustrates the most convenient quality of sticky notes, their removability. Developed in the 1970s as an alternative to conventional bookmarks, post-its owed much of their subsequent success to a unique type of glue powerful enough to ensure proper adhesion, but weak enough to allow an easy detachment without damaging the surface material. ${ }^{20}$ While none of my following medieval examples of affixed tablets are actually removed, they still reveal the poetic possibilities of the inscribed post-it as a temporarily permanent piece of writing.

In Chaucer's House of Fame (c.1380), the dreamer-narrator encounters a plaque attached to the wall of the temple of Venus that bears the beginning of Virgil's Aeneid. While the post-it is clearly a table of bras (142), the walls are made of glass, which would explain why Virgil's verses are not inscribed directly onto the wall. In addition, writing on a wall carries the specific connotation of a prophetic warning. But there is, I believe, another reason why the text features Virgil on a post-it, a reason that is more closely connected to Chaucer's own literary ambitions. As the chapter on inscriptions in British literature in this volume argues, The House of Fame narrates Chaucer's questioning of the cultural auctoritas traditionally accorded to classical authors and his effort to present himself as a "public poet" who draws on contemporary, worldly experience rather than received wisdom. ${ }^{21}$ Virgil's lines attached to, but not written on the temple walls, I would contend, gesture towards an anxiety of influence that is wary of literary models, yet knows how to transcend them.

By representing the echo of the Aeneid on a post-it, Chaucer gives material form to a single voice from the corpus of classical literature underpinning his poem. Singling out Virgil with a brass tablet, he creates an arrangement of the kind that Seeta

20 Petroski 1992 narrates the story of how post-its were invented when an engineer sought to create sticky bookmarks by using an adhesive previously developed for the painting of cars.

21 Cf. p. 88 of this volume. 
Chaganti, writing in a different context, has described as "figure and ground". Borrowed from Gestalttheorie and then developed by fields such as media studies and art theory, the two terms describe a basic relationship in human perception. While some phenomena will be identified as an amorphous (back)ground, "certain shapes and hues dominate one's perceptual field to stand out as figures". ${ }^{22}$ By inscribing Virgil on a material post-it, I would argue, Chaucer isolates one figure of auctoritas against the ground of the glass wall. This material foregrounding prepares the way for a poetic empowerment. In The House of Fame, classical auctoritas is not an all-encompassing horizon; turned into just a piece of writing, a scrap, even Virgil can be (sur)passed, his brass tablet dismounted from the wall or left behind as the dreamer moves on, and his poetry transcended by Chaucer the public poet. As a figure still attached to, but detached from the ground, the material post-it offers a way of confining a piece of writing to a limited space. Chaucer's dreamer uses the Virgilian lines to launch his own literary myth-making. He has the last word, while the tablet remains silent.

Used in a different context, but similarly related to hierarchies of power and speech, post-its also lend themselves to the textual practice of tagging. Affixing a material bit of writing to a person or a thing is an act of appropriation, of superimposing a voice that hijacks the person's or the thing's means of self-representation. Such a tagging may be performed with benevolent intentions, as in case of plaques fastened to funerary monuments and bearing eulogies, of which medieval literature records a considerable number. ${ }^{23}$ But, as the brass tablet in The House of Fame has shown, postits bring power relations into play as their doubleness-text-bearing thing on thing, text-bearing material on material-reveals the agonistic nature of a supplement that both complements and undermines that to which it is attached. In order to explore inscribed tablets as tags, I will turn to possibly the most well-known post-it in Western literature, the INRI inscription.

All four gospels narrate how a nametag for Jesus is affixed to the cross on which he was crucified:

Postquam autem crucifixerunt eum diviserunt vestimenta eius sortem mittentes et sedentes servabant eum. Et inposuerunt super caput eius causam ipsium scriptam hic est Iesus rex Iudaeorum. (Matt. 27:35-37)

And after they had crucified him, they divided his garments, casting lots; [...]. And they sat and watched him. And they put over his head his cause written: THIS IS JESUS THE KING OF THE JEWS.

The tablet positioned above Jesus's head identifies him, in contrast to the two also crucified but untagged thieves whose crosses, as the next sentence makes clear, were

22 Chaganti 2014, 54.

23 According to the CRC database, most plaques serve as epitaphs attached to coffins or statues positioned on the grave. Cf. Laura Velte's chapter on tombs in this volume. 
erected adjacent to Christ's. But the post-it does not simply record the name of the punished man, but also discloses his crime (causam) with the accusatory epithet "King of the Jews". Mark and Luke specify that the tag was "a superscription" (titulus, Mark 15:26; superscriptio, Luke 23:38), referring both to its spatial positioning and its function. To those who argued for Christ's crucifixion, the plaque represents a mark of triumph that aims to supersede Jesus's message by turning his own words against him in a performance of dramatic irony.

One of the gospels, however, also betrays an anxiety about potential misreadings of a post-it so publicly exhibited.

et baiulans sibi crucem exivit in eum qui dicitur Calvariae locum hebraice Golgotha ubi eum crucifixerunt et cum eo alios duos hinc et hinc medium autem Iesum. Scripsit autem et titulum Pilatus et posuit super crucem erat autem scriptum Iesus Nazarenus rex Iudaeorum. Hunc ergo titulum multi legerunt Iudaeorum quia prope civitatem erat locus ubi crucifixus est Iesus et erat scriptum hebraice graece et latine. Dicebant ergo Pilato pontifices Iudaeorum noli scribere rex Iudaeorum sed quia ipse dixit rex sum Iudaeorum. Respondit Pilatus quod scripsi scripsi. (John 19:17-22)

And bearing his own cross, he went forth to the place which is called Calvary, but in Hebrew Golgotha. Where they crucified him, and with him two others, one on each side, and Jesus in the midst. And Pilate wrote a title also: and he put it upon the cross. And the writing was: JESUS OF NAZARETH, THE KING OF THE JEWS. This title therefore many of the Jews did read: because the place where Jesus was crucified was nigh to the city. And it was written in Hebrew, in Greek, and in Latin. Then the chief priests of the Jews said to Pilate: Write not: The King of the Jews. But that he said: I am the King of the Jews. Pilate answered: What I have written, I have written.

John's account of the inscription differs from the one in the Synoptic Gospels in several key details. Here, it is Pontius Pilate who writes and places the post-it, rather than an unidentified group of people. The passage also records the reactions of the Jews, who fear that the epithet on the inscription might be taken as fact rather than as a mockery of Christ's pretension. To ensure that the irony and the Roman victory are not lost on readers, the Jews propose to signal that the voice of the plaque is Christ's, which would overwrite his self-representation with mimicked speech. Pilate's insistence on leaving the post-it as it is instead paves the way for a triumphant reading of Jesus's story, a reading in which written things come true.

One prominent refraction of the INRI inscription features in the fourteenth-century Book of John Mandeville, a travelogue that takes readers from Hungary to East Asia via the Holy Land. In the chapter entitled $A$ way to Ierusalem, the text offers a detailed description of the holy cross. It is made of four different types of wood, each used for a specific purpose. While the beams are made of sweet-smelling cypress, undecaying cedar and palm signifying victory, pe table abouen his heued [...] on pe whilk pe tytle was writen [...] was of olyue (6.33-35) to signify the pees (7.12) the Jews had hoped would reign after the death of Jesus the trouble-maker. Not only the materiality of the plaque is explicated; the narrator also describes its precise measurements (a fote and a halfe long, 6.33f.) in an attempt at verisimilitude. Stopping at this 
moment on Cyprus, he has good reason to emphasise the physical uniqueness of the true cross, contrasting it with a false relic that the Cypriots currently worship on their island. Christ's cross and post-it are portrayed en passant, the details furnished by textual memory rather than autopsy.

When Mandeville's narrator eventually gets to Jerusalem, the true cross is not there either, having been excavated, as we learn, by Constantine and Helena. Still, the holy place is visibly marked by the sacred history that took place there. The particular spot on Golgotha where Christ gave up his spirit is still bleeding (42) and the narrator records two inscriptions, on pare whare oure lord was done on pe crosse (42.27), proclaiming Jesus has worked salvation in this very place, and one apon pe roche whare pe crosse was ficched (42.33), identifying that spot as pe ground of alle pe fayth (42.36f.). In contrast to the INRI epithet, these inscriptions are not incised on tablets, but engraved in the very landscape. The cross and nails have been recovered, whereas the plaque bearing Christ's name never resurfaced. ${ }^{24}$ Instead, the textuality that accompanied the crucifixion has permeated the physical surroundings, where it now illustrates the paradox of temporary permanence. While the post-it itself, material but attached only flimsily, is gone, the message has endured, now inscribed into the very ground itself.

The text-bearing artefact that medieval texts call "tablet", then, is multifaceted, encompassing both the private and the public, the ephemeral and the eternal. As personal writing companions, tablets allow courtly women to process and communicate their emotions and desires in wax, the substance most tolerant of doubts. At the same time, their format evokes divine statutes whose materiality connects Adam and Solomon, and Dido and Lavinia. Tablets easily break when thrown in anger by a brother disgusted at the suggestion of incest, yet survive the first end of the world and testify to how it all began. Posted onto walls and crosses, they generate an agon of voices. New poetry can set itself off as inspired by, but now separate from, the old. And even at the death of Christ, a post-it creates an assemblage in which the inscribed figure seeks but fails to eclipse the silent ground.

24 Interestingly, the INRI tablet is not generally counted among the arma Christi. Even very comprehensive collections of all things to do with Jesus, such as the 38 objects illustrated in the fourteenth-century Omne Bonum encyclopaedia (London, British Library MS Royal 6.E.VI., fol.15r), list all torture instruments as well as objects that did not touch the body of Christ but were related to the scene of the crucifixion, like the dice the soldiers used to gamble for Christ's clothing. The tablet, however, is not among them. Olk 2012, 218f. discusses other vestiges of Christ's life still visible in Mandeville's Jerusalem. 


\section{Works Cited}

\section{Primary sources}

Biblia Sacra. Iuxta vulgatam versionem (1994), ed. by Roger Gryson, Stuttgart.

Canticum de Creatione (1878), in: Sammlung altenglischer Legenden größtentheils zum ersten Male herausgegeben, ed. by Carl Horstmann, Heilbronn.

Chaucer, Geoffrey (1986), The House of Fame, in: The Riverside Chaucer, ed. by Larry D. Benson, Boston.

Eneas (1985), ed. by J.-J. Salverda de Grave (Les Classiques Français du Moyen Age), Paris.

Heinrich von Veldeke (1986), Eneasroman, ed. by Ludwig Ettmüller and trans. into German by Dieter Kartschoke (RUB 8303), Stuttgart.

The Holy Bible. Douay-Rheims Version (1989), rev. by Richard Challoner, Rockford.

Life of Adam and Eve in The Wheatley Manuscript. British Museum MS ADD 39574 (1921), ed. by Mabel Day (Early English Text Series 155), London.

Mandeville's Travels. The Egerton Version (2010), ed. by M. C. Seymour (Early English Text Series 336), Oxford.

Ovide moralisé. Neuvième Livre (1931), ed. by C. de Boer, Martina G. de Boer and Jeannette Th. M. van't Sant (Verhandelingen der Koninklijke Akademie van Wetenschappen te Amsterdam, Afdeeling Letterkunde 30.3), Amsterdam.

Wickram, Georg (1906), Ovids Metamorphosen, in: Georg Wickrams Werke, vol. 8, ed. by Johannes Bolte (Bibliothek des Litterarischen Vereins in Stuttgart 241), Tübingen.

\section{Secondary sources}

Adams, Tracy (2005), Violent Passions. Managing Love in the Old French Verse Romance (Studies in Arthurian and Courtly Cultures), New York.

Archibald, Elizabeth (2001), Incest and the Medieval Imagination, Oxford.

Bennett, Jane (2010), Vibrant Matter. A Political Ecology of Things, Durham/London.

Bourgne, Florence (2011), "Vernacular Engravings in Late Medieval England", in: Leo Carruthers, Raeleen Chai-Elsholz and Tatjana Silec (eds.), Palimpsests and the Literary Imagination of Medieval England (The New Middle Ages), New York, 115-136.

Brown, Michelle P. (1994), "The Role of the Wax Tablet in Medieval Literacy. A Reconsideration in Light of a Recent Find from York", in: The British Library Journal 20 (1), 1-16.

Carr, David M. (2005), Writing on the Tablet of the Heart. Origins of Scripture and Literature, Oxford.

Chaganti, Seeta (2014), “Figure and Ground. Elene's Nails, Cynewulf's Runes, and Hrabanus Maurus's Painted Poems", in: Lisa H. Cooper and Andrea Denny-Brown (eds.), The Arma Christi in Medieval and Early Modern Material Culture, Farnham, 53-82.

Cormier, Raymond (2006), "À propos de Lavine amoureuse. Le savoir sentimental féminin et cognitif”, in: Bien dire et bien aprandre 24, issue: Réception et représentation de l'Antiquité, ed. by Aimé Petit, 57-70.

Cruse, Mark (2007), “Intimate Performance. An Ivory Writing Tablet Cover at The Cloisters”, in: Eglal Doss-Quinby, Roberta L. Krueger and E. Jane Burns (eds.), Cultural Performances in Medieval France. Essays in Honor of Nancy Freeman Regalado, Rochester, 57-69.

Dean, James M. (2010), “Domestic and Material Culture in the Middle English Adam Books", in: Studies in Philology 107 (1), 25-47. 
Gertz, Jan Christian (2016), “Mose zerbricht die Tafeln des Bundes am Sinai. Literarhistorisch ausgereizt, aber praxeologisch unterschätzt?", in: Friedrich-Emanuel Focken and Michael R. Ott (eds.), Metatexte. Erzählungen von schrifttragenden Artefakten in der alttestamentlichen und mittelalterlichen Literatur (Materiale Textkulturen 15), Berlin/Boston, 177-201.

Jager, Eric (1996), “The Book of the Heart. Reading and Writing the Medieval Subject”, in: Speculum 71(1), 1-26.

Mills, Robert (2015), Seeing Sodomy in the Middle Ages, Chicago/London.

Murdoch, Brian (2009), The Apocryphal Adam and Eve in Medieval Europe. Vernacular Translations and Adaptations of the Vita Adae et Evae, Oxford.

Nolan, Barbara (1992), Chaucer and the Tradition of the Roman Antique (Cambridge Studies in Medieval Literature 15), Cambridge.

Novacich, Sarah Elliott (2017), Shaping the Archive in Late Medieval England. History, Poetry, and Performance, Cambridge.

Olk, Claudia (2012), "The Poetics of Jerusalem in Mandeville's Travels", in: Annette Hoffmann and Gerhard Wolf (eds.), Jerusalem as Narrative Space. Erzählraum Jerusalem, Leiden/Boston 2012, 211-230.

Petroski, Henry (1992), “Let Us Now Praise the Humble Post-It”, in: The Wilson Quarterly 16 (4), 104-110.

Quast, Bruno and Monika Schausten (2008), “Amors Pfeil. Liebe zwischen Medialisierung und Mythisierung in Heinrichs von Veldeke Eneasroman", in: Mireille Schnyder (ed.), Schrift und Liebe in der Kultur des Mittelalters (Trends in Medieval Philolgy 13), Berlin/New York, 63-82.

Robson, Eleanor (2007), “The Clay Tablet Book in Sumer, Assyria, and Babylonia”, in: Simon Eliot and Jonathan Rose (eds.), A Companion to the History of the Book, Malden, 67-83.

Rouse, Richard H./Rouse, Mary A. (2013), Bound Fast with Letters. Medieval Writers, Readers, and Texts, Notre Dame.

Wuth, Henning (1997), "was, strâle unde permint. Mediengeschichtliches zum Eneasroman Heinrichs von Veldeke”, in: Horst Wenzel (ed.), Gespräche - Boten - Briefe. Körpergedächtnis und Schriftgedächtnis im Mittelalter, Berlin, 63-76. 
